\title{
Utilization of Compost and Compost Tea for Improving Egyptian Hybrid Rice One Cultivar
}

\author{
Nehal M. Elekhtyar, B. B. Mikhael and Mariam T. Wissa \\ Rice Research and Training Center (RRTC), Field Crops Research Institute (FCRI) - \\ Agricultural Research Center (ARC), Egypt.
}

\begin{abstract}
DRESENTLY, Compost and compost tea with additional chemical fertilizers increase the organic carbon and soluble salts of soil, finally enhance the productivity of Egyptian hybrid rice one $\left(\mathrm{H}_{1}\right)$. A field experiment was conducted in two successive seasons 2015 and 2016 at the experimental farm of Rice Research and Training Center (RRTC), Sakha, Kafrelsheikh, Egypt; to evaluate the influence of different chemical fertilizers (NPK) levels with combined compost and compost tea on yield, yield attributes, chemical compositions and quality of grains of Egyptian hybrid rice one. A randomized Complete Block Design with four replications was used. The results indicated that there were significant positive effects of chemical NPK fertilizers with compost and compost tea on number of panicles $\mathrm{m}^{-2}$ at harvest, filled grain percentage, 1000-grain weight, $\mathrm{N}$ uptake in grain and straw, phosphorus and potassium content as well as grain quality. Combination of chemical fertilizers with compost and compost tea were gave the maximum crop yield as well as all the previous characters higher than for the single application of organic or chemical fertilizer alone. Thus, it concluded that the applying $\mathrm{N}_{110} \mathrm{P}_{24} \mathrm{~K}_{40}+$ compost as organic fertilizer + compost tea as bio-organic fertilizer could be used successfully to enhance the productivity of Egyptian hybrid rice one, without any significantly differences with $\mathrm{N}_{165} \mathrm{P}_{36} \mathrm{~K}_{60}$ as recommended NPK doses. Integrated use of chemical NPK fertilizer with compost or compost tea positively affected the yield attributes and yield of hybrid rice and contributed in reducing chemical NPK fertilizers by $1 / 3$ as well as minimizing the cost of inputs and environmental pollution.
\end{abstract}

Keywords: Oryza sativa L., Hybrid rice, Bio-organic agriculture, Compost, Compost tea, Chemical NPK, Chemical compositions.

\section{Introduction}

Rice (Oryza sativa L.), is one of the major field crops in the world as a staple food source and is widely cultivated in Egypt. Hybrid rice is producing from a cross between two genetically distinct rice parents, so when the right parents are selected, the hybrid will have both greater vigor and yield than either of the parents (Xie et al., 2007). Hybrid rice proved more remunerative than high yielding commercial varieties. The Egyptian farmers used the large amounts of chemical fertilizers to supply the requirements of rice crop. This is very costly and causes environmental pollution. Crop scientists all over the world are facing this alarming situation and they are trying to overcome this problem by exploring alternative sources, which is cost effective and save the environment. Bio or organic fertilizers an alternative source of chemical fertilizers. Bio and organic fertilizers affect plant growth by producing and releasing secondary metabolites (plant growth regulators, phytohormones and biologically active substances), facilitating the availability and uptake of certain nutrients from the root environment and inhibiting plant pathogenic organisms in the rhizosphere (Elekhtyar, 2011).

Compost had a significant effect on all mentioned growth characters of Egyptian 101 rice cultivar, significantly increased number of panicles per $\mathrm{m}^{2}$, total grain number panicle ${ }^{-1}$, percentage of filled grains, panicle weight, straw yield, grain yield and harvest index, also produced great nitrogen content in flag leaf, nitrogen uptake in flag leaf, nitrogen uptake in grain, nitrogen uptake in straw, total nitrogen uptake, protein content in grain, protein content in straw, protein yield of grain, protein yield of straw and total protein yield. Moreover, the application of compost saved about one third from the recommended doses of nitrogen. (Elekhtyar, 2007). Compost tea is a solution fermented by fungus namely Trichoderma spp. This technology 
can increase the growth and development of rice plant. Compost tea as foliar spray + biofertilizer $+75 \%$ chemical NPK are recommended, whereas it attained high net value $\left(859.1 \$ \mathrm{ha}^{-1}\right)$ and contributes in reducing chemical fertilizers $(\mathrm{N}, \mathrm{P}$ and $\mathrm{K}$ ) by $25 \%$, the matter which produce more clean environment and soil conservation (Elekhtyar et al., 2016). The co-application of chemical and organic fertilizers is the suitable opportunity to improve soil nutrients and crops productivity (Nigussie et al., 2015). This study was done to investigate the influence of compost as basal application and compost tea as foliar spray with doses of chemical NPK fertilizers to Egyptian hybrid rice one.

\section{Materials and Methods}

The experiments were carried out at Rice Research and Training Center (RRTC), Sakha, Kafrelsheikh, Egypt; during 2015 and 2016 seasons to study the effect of compost and compost tea on yield attributes, yield, grain quality characters and chemical compositions of Egyptian hybrid rice one $\left(\mathrm{H}_{1}\right)$. Representative soil samples were taken from each site at the depth of 0-30 cm from the soil surface. Samples were air-dried then ground to pass through a two $\mathrm{mm}$ sieve and properly mixed. The procedure of soil analysis followed the methods described by Black et al. (1965). Some chemical properties of the soil in the experimental site are presented in Table 1.

TABLE 1. Soil chemical properties of the experimental sites in 2015 and 2016 seasons

\begin{tabular}{|c|c|c|c|c|c|c|c|c|c|c|c|}
\hline \multirow{2}{*}{ Season } & \multicolumn{3}{|c|}{$\begin{array}{c}\text { Soluble anions } \\
\left(\text { meq } \mathbf{L}^{-1}\right)\end{array}$} & \multicolumn{4}{|c|}{$\begin{array}{l}\text { Soluble cations } \\
\left(\mathrm{meq}^{-1}\right)\end{array}$} & \multicolumn{3}{|c|}{$\begin{array}{l}\text { Available micro-nutrients } \\
\qquad\left(\mathrm{mg} \mathrm{kg}^{-1}\right)\end{array}$} & \multirow{2}{*}{$\begin{array}{c}\text { Available } \\
\mathrm{NH}_{4}^{+} \\
\left(\mathrm{mg} \mathrm{kg}^{-1}\right)\end{array}$} \\
\hline & $\mathrm{HCO}_{3}^{-}$ & $\mathrm{Cl}^{-}$ & $\mathrm{SO}_{4}^{--}$ & $\mathrm{Ca}^{++}$ & $\mathbf{M g}^{++}$ & $\mathbf{K}^{+}$ & $\mathbf{N a}^{++}$ & $\mathbf{F e}^{++}$ & $\mathbf{M n}^{++}$ & $\mathbf{Z n}^{++}$ & \\
\hline 2015 & 5.60 & 14 & 2.70 & 7.20 & 2.60 & 0.50 & 12 & 5.80 & 3.20 & 0.95 & 13.5 \\
\hline 2016 & 5.00 & 14 & 2.00 & 6.00 & 1.50 & 0.50 & 13 & 5.20 & 3.00 & 1.05 & 12.6 \\
\hline
\end{tabular}

Soil texture: Clayey, Soil $\mathrm{pH}$ was measured in 1:2.5 water suspension.

TABLE 1. Cont.

\begin{tabular}{l|c|c|c|c|c}
\hline Season & $\begin{array}{c}\text { Available P } \\
\left(\mathbf{m g ~ k g}^{-1}\right)\end{array}$ & $\begin{array}{c}\text { Available K } \\
\left(\mathbf{m g ~ k g}^{-1}\right)\end{array}$ & $\mathbf{E c}\left(\mathbf{d S ~ m}^{-1}\right)$ & $\mathbf{p H}$ & Organic Matter (\%) \\
\hline 2015 & 14.0 & 366 & 2.0 & 8.05 & 1.65 \\
\hline 2016 & 12.0 & 350 & 2.05 & 8.2 & 1.50 \\
\hline
\end{tabular}

Seeds at the rate of $24 \mathrm{~kg} \mathrm{ha}^{-1}$ were soaked in water for $24 \mathrm{hr}$ then incubated for $48 \mathrm{hr}$ to hasten early germination. Pre-germinated seeds were uniformly broadcasted in the nursery on $15^{\text {th }}$ May of the two seasons. The permanent field was prepared, through plowed twice followed by good wet leveling. Seedlings were carefully pulled from the nursery after 30 days from sowing date and distributed among the plots. Seedlings were manually transplanted into $12 \mathrm{~m}^{2}$ sub plots in $20 \times 20 \mathrm{~cm}$ spacing at the rate of $2-3$ seedlings hill${ }^{1}$. Plots were kept flooded till 2-3 weeks before harvesting. All other agronomic practices were followed as recommended during the growing season. The preceding crop was barely in the two seasons.

The NPK chemical fertilizer treatments included: $\mathrm{N}_{165} \mathrm{P}_{36} \mathrm{~K}_{60}$ and $\mathrm{N}_{110} \mathrm{P}_{24} \mathrm{~K}_{40}$ as recommended doses of chemical NPK and two third of recommended respectively of Egyptian hybrid rice one fertilizer needs. Nitrogen fertilizer was applied in the form of urea $(46.5 \% \mathrm{~N})$ were applied in two equal splits, the first half as basal application and incorporated into the soil then immediately the soil was flooded. The second dose was top-dressed at 30 days after transplanting (DAT). Phosphorus fertilizer was applied in the form of single super phosphate $\left(15.5 \% \mathrm{P}_{2} \mathrm{O}_{5}\right)$ and Potassium fertilizer was applied in the form of potassium sulfate $\left(50 \% \mathrm{~K}_{2} \mathrm{O}\right)$ in the permanent field and incorporated into soil during land preparation. The usual agricultural practices of growing rice were performed as the recommendation of Rice Research and Training Center (RRTC).

Compost was prepared from rice straw. Rice straw was chopped to small parts and gathered in a well-drained. The straw was mixed with $20 \mathrm{~kg}$ urea and $15 \mathrm{~kg}$ super phosphate and farm yard manure besides fungus (Trichoderma $s p$ ). These materials were put in layers and water was sprayed between layers. By the last layer the heap 
was covered with plastic sheet. The heap was turned from top to bottom every 2 weeks. The compost was harvested after 12 weeks. Compost at the rate of $12 \mathrm{tha}^{-1}$ were transported to plots and incorporated basely into the dry soil surface, during plots preparation before rice transplanting, (Elekhtyar, 2007). The bio-organic fertilizer namely compost tea was used at the rate of 50 liter ha ${ }^{-1}$ mixed with water for foliar spray in the permanent field at 40 DAT. The bio-organic was produced by Bacteriology Lab., Sakha Agricultural Research Station, Sakha, Kafrelsheikh, Egypt. The chemical analysis of compost and compost tea were carried out using standard analytical methods. Chemical composition of compost and compost tea are shown in Table 2.

TABLE 2. Chemical composition of Compost and compost tea in 2015 and 2016 seasons

\begin{tabular}{|c|c|c|c|c|c|c|c|c|c|c|}
\hline \multirow[b]{2}{*}{ Season } & \multicolumn{5}{|c|}{ Compost } & \multicolumn{5}{|c|}{ Compost tea } \\
\hline & $\begin{array}{l}\mathbf{N} \\
\% \\
\end{array}$ & $\begin{array}{l}\mathbf{P} \\
\% \\
\end{array}$ & $\begin{array}{l}\mathbf{K} \\
\% \\
\end{array}$ & $\begin{array}{l}\mathbf{C} \\
\% \\
\end{array}$ & $\mathrm{C} / \mathrm{N}$ ratio & $\begin{array}{l}\mathbf{N} \\
\% \\
\end{array}$ & $\begin{array}{l}\mathbf{P} \\
\%\end{array}$ & $\begin{array}{l}\mathbf{K} \\
\% \\
\end{array}$ & $\begin{array}{l}\mathbf{C} \\
\% \\
\end{array}$ & $\begin{array}{l}\mathrm{C} / \mathrm{N} \\
\text { ratio }\end{array}$ \\
\hline 2015 & 1.63 & 0.72 & 0.94 & 7.11 & $5.21: 1$ & 1.84 & 0.79 & 1.13 & 9.02 & $6.45: 1$ \\
\hline 2016 & 1.58 & 0.68 & 0.89 & 7.60 & 4.94:1 & 1.77 & 0.70 & 1.05 & 8.63 & 5.90:1 \\
\hline
\end{tabular}

Treatments

$\mathrm{T}_{1}: \mathrm{N}_{165} \mathrm{P}_{36} \mathrm{~K}_{60}=165$ Urea: $36 \mathrm{P}_{2} \mathrm{O}_{5}: 60 \mathrm{~K}_{2} \mathrm{O}(\mathrm{kg}$ ha $\left.^{-1} \mathrm{NPK}\right)$. (Recommended \& Control)

$\mathrm{T}_{2}: \mathrm{N}_{110} \mathrm{P}_{24} \mathrm{~K}_{40}=110$ Urea: $24 \mathrm{P}_{2} \mathrm{O}_{5}: 40 \mathrm{~K}_{2} \mathrm{O}(\mathrm{kg}$ $\left.\mathrm{ha}^{-1} \mathrm{NPK}\right)$.

$\mathrm{T}_{3}: \mathrm{N}_{110} \mathrm{P}_{24} \mathrm{~K}_{40}+$ Compost

$\mathrm{T}_{4}: \mathrm{N}_{110} \mathrm{P}_{24} \mathrm{~K}_{40}+$ Compost tea

$\mathrm{T}_{5}: \mathrm{N}_{110} \mathrm{P}_{24} \mathrm{~K}_{40}+$ Compost + Compost tea

$\mathrm{T}_{6}:$ Compost + Compost tea

$\mathrm{T}_{7}: \mathrm{N}_{0} \mathrm{P}_{0} \mathrm{~K}_{0}=0$ Urea: $0 \mathrm{P}_{2} \mathrm{O}_{5}: 0 \mathrm{~K}_{2} \mathrm{O}\left(\mathrm{kg} \mathrm{ha}^{-1} \mathrm{NPK}\right)$.

Chemical compositions: Nitrogen uptake in grain and straw was determined at harvest using orange- $\mathrm{G}$ dye method (Hafez and Mikkelson, 1981) and measured by spectrophotometer, Phosphorus concentration in grain was extracted as described by (Peterpurgski, 1968) and measured by spectrophotometer using ascorbic acid method (Page et al., 1982) and potassium concentration in grain was determined using the Flame photometer method (Peterpurgski, 1968).

\section{Studied characteristics}

Number of panicles $\mathrm{m}^{-2}$, filled grain (\%), 1000 -grain weight $(\mathrm{g})$, phosphorus and potassium content in grain, hulling percentage, milling percentage, head rice percentage, nitrogen uptake in grain and straw $\left(\mathrm{kg} \mathrm{ha}^{-1}\right)$ was calculated as follows: $\mathrm{N}$ uptake $=\mathrm{N} \% \times$ grain or straw dry weight, grain yield ( $\left.\mathrm{tha}^{-1}\right)$ and straw yield $\left(\mathrm{t} \mathrm{ha}^{-1}\right)$.

$\begin{array}{ll}\begin{array}{l}\text { Percentage of filled } \\ \text { grains }=\end{array} & \begin{array}{l}\text { No. of filled grains } \\ \text { panicle }{ }^{-1}\end{array} \\ \begin{array}{l}\text { Total No. of grains } \\ \text { panicle }\end{array} & \begin{array}{l}\text { Brown rice weight }(\mathrm{g}) \\ \text { Hulling } \%=\end{array} \\ \text { Milling \% }=\quad \begin{array}{l}\text { Rough rice weight }(\mathrm{g})^{-1} \\ \text { Milled rice weight }(\mathrm{g})\end{array} \times 100\end{array}$

$$
\text { Head rice } \%=\quad \text { head rice weight }(\mathrm{g}) \quad \times 100
$$

Hulling\%, milling\% and head rice $\%$ were estimated according to the methods reported by Adair (1952). All collected data were statistically analyzed according to the technique of analysis of variance as a Randomized Complete Block Design (RCBD) analysis for the two seasons and the Duncan's Multiple Range Test (DMRT), 1955 was used to test the difference among the treatment means as published by Gomez and Gomez (1984). All statistical analysis was performed using analysis of variance technique using "MSTAT-C" computer software package.

\section{$\underline{\text { Results and Discussion }}$}

The data presented in Table 3 revealed that number of panicle $\mathrm{m}^{-2}$ at harvest, filled grain percentage and 1000-grain weight of Egyptian hybrid rice one cultivar $\left(\mathrm{H}_{1}\right)$ as affected by compost and compost tea in 2015 and 2016 seasons. Number of panicle $\mathrm{m}^{-2}$ at harvest and filled grain percentage significantly increased by application of $\mathrm{N}_{110} \mathrm{P}_{24} \mathrm{~K}_{40}$ (110 Urea: $24 \mathrm{P}_{2} \mathrm{O}_{5}: 40 \mathrm{~K}_{2} \mathrm{O} \mathrm{kg} \mathrm{ha}{ }^{-1}$ NPK) as two third of recommended doses of chemical NPK + basal application of compost as organic fertilizer + foliar spray of compost tea as bio-organic fertilizer in the permanent field at 40 days after transplanting (DAT) without any significantly differences with $\mathrm{N}_{165} \mathrm{P}_{36} \mathrm{~K}_{60}$ (165 Urea: $36 \mathrm{P}_{2} \mathrm{O}_{5}$ : $60 \mathrm{~K}_{2} \mathrm{O} \mathrm{kg} \mathrm{ha-1)}$ as recommended NPK doses. The increase in number of panicle $\mathrm{m}^{-2}$ at harvest and filled grain percentage may be due to the more availability of nitrogen which release from compost by mineralization process in paddy soil that is due to conversion of organic 
forms of $\mathrm{N}$ to inorganic $\mathrm{N}$ as ammonium $\left(\mathrm{NH}_{4}^{+}\right)$ as available form of $\mathrm{N}$ to uptake by rice plant to play a vital role in cell division (Elekhtyar, 2007). The implementation of compost to soil can affect soil fertility by modifying the physical, chemical and biological properties of the soil, the chemical changes include enhancement nutrients content of the paddy soil . These results are in accordance with the findings of (Gajalakshmi et al., 2008). One thousand grains weight significantly increased with zero chemical NPK fertilizers then compost and compost tea without any chemical fertilizers. The maximum 1000 grains weight was produced with unfertilized treatment and this increase with the lowest level of fertilizer is mainly due to a decrease in the number of spikelet's panicle ${ }^{-1}$ which consequently increases the filling spikelet's panicle $^{-1}$. These results are in harmony with those indicated by Elekhtyar (2015 a and b). Except 1000-grain weight, unfertilized treatment or fertilized with compost and compost tea without any chemical fertilizers recorded the lowest yield attributes of Egyptian hybrid rice one cultivar that may be due to the single application of compost to provide the nutrients for crops may not sufficient; hence, the adding of chemical fertilizers to compost is helpful (Hargreaves et al., 2008).

Different combinations of compost and compost tea with chemical fertilizers had significant effects on nitrogen uptake in grain and straw of Egyptian hybrid rice one cultivar in 2015 and 2016 seasons (Table 4). The maximum values of nitrogen uptake in grain and straw were obtained with the treatment of $\mathrm{N}_{110} \mathrm{P}_{24} \mathrm{~K}_{40}$ (110 Urea: $24 \mathrm{P}_{2} \mathrm{O}_{5}$ : $40 \mathrm{~K}_{2} \mathrm{O} \mathrm{kg} \mathrm{ha}{ }^{-1} \mathrm{NPK}$ ) as two third of recommended doses of chemical NPK + basal application of compost as organic fertilizer + foliar spray of compost tea as bio-organic fertilizer in the permanent field at 40 days after transplanting (DAT). Compost and compost tea with chemical fertilizers significantly increased nitrogen uptake in grain and straw in both seasons and higher than recommended doses of NPK $\left(\mathrm{N}_{165} \mathrm{P}_{36} \mathrm{~K}_{60}\right)$. Increasing $\mathrm{N}$ uptake in grain and straw of Egyptian hybrid rice one cultivar may be due to the more availability of nitrogen which release from compost and compost tea by mineralization process in paddy soil that is due to conversion of organic forms of $\mathrm{N}$ to inorganic $\mathrm{N}$ as ammonium $\left(\mathrm{NH}_{4}^{+}\right)$as available form of $\mathrm{N}$ to uptake by rice plant (Elekhtyar, 2007). On the other hand, compost mixed with chemical fertilizer can act as a source of $\mathrm{N}$ slow and immediate release and provide needed nitrogen for different growth periods of the plant. The solubilize amount of soluble salts in soils, the amendments of compost and compost complemented with additional chemical fertilizer promoted an increase in soil organic carbon (Wang and Yang, 2003). Also Compost and compost tea application leads to enhanced enrichment of organic nitrogen in the soil (Gajalakshmi et al., 2008) and significantly increased $\mathrm{NH}_{4}^{+}$concentration in rice soil (Surekha et al., 2006). Soils amended with organic fertilizers have lower bulk density and higher aggregate stability than mineral-fertilized soils (Lal, 2009). Unfertilized treatment or fertilized with compost and compost tea without any chemical fertilizers recorded the lowest values. Hargreaves et al. (2008) reported that the single application of compost to provide the nutrients for crops may not sufficient; hence, the adding of chemical fertilizers to compost is helpful. Moreover, the single application of compost may suppress the microbial activities of the soil since it has a high

TABLE 3. Number of panicle $\mathrm{m}^{-2}$, Filled grain percentage and 1000-grain weight of Egyptian hybrid rice one cultivar $\left(\mathrm{H}_{1}\right)$ as affected by compost and compost tea in 2015 and 2016 seasons

\begin{tabular}{lcccccc}
\hline & Treatments & No. of panicles $\mathbf{~ m}^{-2}$ & at harvest & \multicolumn{2}{c}{ filled grain \% } & \multicolumn{1}{c}{ 1000-grain wt. (g) } \\
& $\mathbf{2 0 1 5}$ & $\mathbf{2 0 1 6}$ & $\mathbf{2 0 1 5}$ & $\mathbf{2 0 1 6}$ & $\mathbf{2 0 1 5}$ & $\mathbf{2 0 1 6}$ \\
\hline $\mathrm{N}_{165} \mathrm{P}_{36} \mathrm{~K}_{60}$ & $652.9 \mathrm{bc}$ & $628.7 \mathrm{c}$ & 91.54 & $91.88 \mathrm{ab}$ & $22.67 \mathrm{~d}$ & $22.37 \mathrm{de}$ \\
$\mathrm{N}_{110} \mathrm{P}_{24} \mathrm{~K}_{40}$ & $622.3 \mathrm{~d}$ & $600.1 \mathrm{~d}$ & $86.86 \mathrm{c}$ & $85.21 \mathrm{~d}$ & $24.64 \mathrm{c}$ & $24.23 \mathrm{c}$ \\
$\mathrm{N}_{110} \mathrm{P}_{24} \mathrm{~K}_{40}+$ Compost & $647.2 \mathrm{c}$ & $642.0 \mathrm{bc}$ & $89.78 \mathrm{~b}$ & $90.28 \mathrm{c}$ & $23.11 \mathrm{~d}$ & $23.75 \mathrm{c}$ \\
$\mathrm{N}_{110} \mathrm{P}_{24} \mathrm{~K}_{40}+$ Compost tea & $667.6 \mathrm{ab}$ & $669.4 \mathrm{ab}$ & 91.33 & $91.35 \mathrm{bc}$ & $23.15 \mathrm{~d}$ & $22.58 \mathrm{~d}$ \\
$\mathrm{~N}_{110} \mathrm{P}_{24} \mathrm{~K}_{40}+$ Compost + Compost tea & $680.1 \mathrm{a}$ & $682.6 \mathrm{a}$ & $93.13 \mathrm{a}$ & $92.93 \mathrm{a}$ & $21.74 \mathrm{e}$ & $21.62 \mathrm{e}$ \\
Compost + Compost tea & $591.3 \mathrm{e}$ & $579.3 \mathrm{de}$ & $82.26 \mathrm{~d}$ & $83.18 \mathrm{e}$ & $25.62 \mathrm{~b}$ & $25.92 \mathrm{~b}$ \\
$\mathrm{~N}_{0} \mathrm{P}_{0} \mathrm{~K}_{0}$ & $574.3 \mathrm{f}$ & $553.0 \mathrm{e}$ & $80.19 \mathrm{e}$ & $80.22 \mathrm{f}$ & $26.92 \mathrm{a}$ & $26.78 \mathrm{a}$ \\
F. test & $* *$ & $* *$ & $* *$ & $* *$ & $* *$ & $* *$ \\
\hline$*$
\end{tabular}

** indicate $\mathrm{P}<0.05, \mathrm{P}<0.01$ and not significant, respectively. Means of each factor designated by the same latter in a column are not significantly different at 0.05 level using Duncan's Multiple Range Test (DMRT). 
TABLE 4. Nitrogen uptake in grain and nitrogen uptake in straw of Egyptian hybrid rice one cultivar $\left(\mathrm{H}_{1}\right)$ as affected by compost and compost tea in 2015 and 2016 seasons

\begin{tabular}{lcccc}
\hline \multicolumn{1}{c}{ Treatments } & \multicolumn{2}{c}{$\begin{array}{c}\text { Nuptake in grain } \\
\left(\mathbf{t} \mathbf{~ h a}^{-1} \mathbf{)}\right.\end{array}$} & $\begin{array}{c}\text { N uptake in straw } \\
\left(\mathbf{t} \mathbf{~ h a}^{-1}\right)\end{array}$ \\
& $\mathbf{2 0 1 5}$ & $\mathbf{2 0 1 6}$ & $\mathbf{2 0 1 5}$ & $\mathbf{2 0 1 6}$ \\
\hline $\mathrm{N}_{165} \mathrm{P}_{36} \mathrm{~K}_{60}$ & $0.0987 \mathrm{~b}$ & $0.0970 \mathrm{ab}$ & $0.0684 \mathrm{~b}$ & $0.0685 \mathrm{bc}$ \\
$\mathrm{N}_{110} \mathrm{P}_{24} \mathrm{~K}_{40}$ & $0.0861 \mathrm{~d}$ & $0.0846 \mathrm{c}$ & $0.0589 \mathrm{~d}$ & $0.0525 \mathrm{~d}$ \\
$\mathrm{~N}_{110} \mathrm{P}_{24} \mathrm{~K}_{40}+$ Compost & $0.0938 \mathrm{c}$ & $0.0914 \mathrm{~b}$ & $0.0609 \mathrm{c}$ & $0.0606 \mathrm{c}$ \\
$\mathrm{N}_{110} \mathrm{P}_{24} \mathrm{~K}_{40}+$ Compost tea & $0.0977 \mathrm{~b}$ & $0.0971 \mathrm{ab}$ & $0.0701 \mathrm{~b}$ & $0.0701 \mathrm{~b}$ \\
$\mathrm{~N}_{110} \mathrm{P}_{24} \mathrm{~K}_{40}+$ Compost + Compost tea & $0.1013 \mathrm{a}$ & $0.1021 \mathrm{a}$ & $0.0812 \mathrm{a}$ & $0.0789 \mathrm{a}$ \\
Compost + Compost tea & $0.0717 \mathrm{e}$ & $0.0573 \mathrm{e}$ & $0.0528 \mathrm{e}$ & $0.0503 \mathrm{~d}$ \\
$\mathrm{~N}_{0} \mathrm{P}_{0} \mathrm{~K}_{0}$ & $0.0636 \mathrm{f}$ & $0.0633 \mathrm{~d}$ & $0.0525 \mathrm{e}$ & $0.0501 \mathrm{~d}$ \\
F. test & $* *$ & $* *$ & $* *$ & $* *$ \\
\hline
\end{tabular}

** indicate $\mathrm{P}<0.05, \mathrm{P}<0.01$ and not significant, respectively. Means of each factor designated by the same latter in a column are not significantly different at 0.05 level using Duncan's Multiple Range Test (DMRT).

$\mathrm{C} / \mathrm{N}$ ratio. In this case, the soil microbe competes with crops to uptake the $\mathrm{N}$ (Amlinger et al., 2003)

Chemical compositions such as phosphorus and potassium content in grain of Egyptian hybrid rice one cultivar in 2015 and 2016 seasons as affected by the application of compost and compost tea with chemical fertilizers, Table (5). The highest percentage value of $\mathrm{P}$ and $\mathrm{K}$ was recorded at the treatment of $\mathrm{N}_{110} \mathrm{P}_{24} \mathrm{~K}_{40}$ (110 Urea: $\left.24 \mathrm{P}_{2} \mathrm{O}_{5}: 40 \mathrm{~K}_{2} \mathrm{O} \mathrm{kg} \mathrm{ha}{ }^{-1} \mathrm{NPK}\right)$ as two third of recommended doses of chemical NPK + basal application of compost as organic fertilizer + foliar spray of compost tea as bio-organic fertilizer in the permanent field at 40 days after transplanting (DAT), without any significant differences with foliar spray of compost tea $+\mathrm{N}_{110} \mathrm{P}_{24} \mathrm{~K}_{40}$ (110 Urea: $24 \mathrm{P}_{2} \mathrm{O}_{5}: 40 \mathrm{~K}_{2} \mathrm{O} \mathrm{kg}$ $\left.\mathrm{ha}^{-1} \mathrm{NPK}\right)$. Increasing the content of $\mathrm{P}$ and $\mathrm{K}$ in grain of Egyptian hybrid rice one cultivar may be due to the $\mathrm{P}$ movement in the soil that depends largely on biotic and abiotic conditions of the soil and enzymes responsible for $\mathrm{P}$ mineralization may be obtained from microorganisms in the soil, plants' root and sources of organic fertilizers, the use of bioorganic fertilizers stabilizes $\mathrm{P}$ and increases microbial activity in the soil that finally resulted in increased availability of $\mathrm{P}$ for the plants. One of the reasons of increased solubility of $\mathrm{P}$ as a result of adding compost is the presence of high $\mathrm{P}$ in compost and compost tea and the formation of humic phosphate complexes which slow the process of phosphorus fixation in the soil (Laboski and Lamb, 2003). On the other hand, soil K concentration was increased when a small amount of compost is used which was due to the absorption of available $\mathrm{K}$ in the compost (Hargreaves et al., 2008). Application of chemical fertilizer together with compost accelerated the decrease in the organic $P$ fraction and mobilizes $\mathrm{K}$ in paddy soils (Ranjbar et al., 2016). Showed that up-taken $P$ and $K$ by crop grown in soil amended with compost were higher than crop grown in soil which received chemical fertilizer. The compost nutrients gradually and continuously become available in soil and to the plant, so it can be used is more than one growing season, and the loss of nutrients' is less as well as reduced leaching of nutrients. Compost provides available elements, stimulates microbial activity and run preserves nutrients and organic matter (Bhattacharyya et al., 2005). Also compost enriched with chemical fertilizers in the farm increase availability of highly used elements by products and rise soil fertility and productivity (Ramadass and Palaniyandi, 2007). Use of organic matter in the soil increased available $\mathrm{P}$ to plants and indirectly prevented phosphate deposits as iron phosphate, aluminum phosphate and calcium phosphate as nonabsorbable for plants. In order to investigate the effect of compost on $\mathrm{K}$ uptake by rice plant it has been shown that due to the use of compost the amount of $\mathrm{K}$ uptake by grains and shoots of the plant was increased (Bhattacharyya et al., 2007). Unfertilized treatment or fertilized with compost and compost tea without any chemical fertilizers recorded the lowest $\mathrm{P} \%$ and $\mathrm{K} \%$ in two seasons, this may due to the single application of compost to provide the nutrients for crops may not sufficient; hence, the adding of chemical fertilizers to compost is helpful. 
TABLE 5. Phosphorus $(P)$ and potassium $(K)$ content in grain of Egyptian hybrid rice one cultivar $\left(H_{1}\right)$ as affected by compost and compost tea in 2015 and 2016 seasons

\begin{tabular}{lcccc}
\hline \multicolumn{1}{c}{ Treatments } & \multicolumn{2}{c}{$\mathbf{P \%}$} & \multicolumn{2}{c}{ K\% } \\
& $\mathbf{2 0 1 5}$ & $\mathbf{2 0 1 6}$ & $\mathbf{2 0 1 5}$ & $\mathbf{2 0 1 6}$ \\
\hline $\mathrm{N}_{165} \mathrm{P}_{36} \mathrm{~K}_{60}$ & $0.2203 \mathrm{~b}$ & $0.2187 \mathrm{ab}$ & $0.2857 \mathrm{~b}$ & $0.2887 \mathrm{~b}$ \\
$\mathrm{~N}_{110} \mathrm{P}_{24} \mathrm{~K}_{40}$ & $0.1923 \mathrm{c}$ & $0.1877 \mathrm{c}$ & $0.2353 \mathrm{~d}$ & $0.2250 \mathrm{~d}$ \\
$\mathrm{~N}_{110} \mathrm{P}_{24} \mathrm{~K}_{40}+$ Compost & $0.2120 \mathrm{~b}$ & $0.2083 \mathrm{~b}$ & $0.2523 \mathrm{c}$ & $0.2515 \mathrm{c}$ \\
$\mathrm{N}_{110} \mathrm{P}_{24} \mathrm{~K}_{40}+$ Compost tea & $0.2227 \mathrm{ab}$ & $0.2233 \mathrm{ab}$ & $0.2964 \mathrm{~b}$ & $0.2910 \mathrm{ab}$ \\
$\mathrm{N}_{110} \mathrm{P}_{24} \mathrm{~K}_{40}+$ Compost + Compost tea & $0.2373 \mathrm{a}$ & $0.2320 \mathrm{a}$ & $0.3107 \mathrm{a}$ & $0.2966 \mathrm{a}$ \\
Compost + Compost tea & $0.1727 \mathrm{~d}$ & $0.1640 \mathrm{~d}$ & $0.1980 \mathrm{e}$ & $0.2027 \mathrm{e}$ \\
$\mathrm{N}_{0} \mathrm{P}_{0} \mathrm{~K}_{0}$ & $0.1450 \mathrm{e}$ & $0.1477 \mathrm{e}$ & $0.1713 \mathrm{f}$ & $0.1683 \mathrm{f}$ \\
F. test & $* *$ & $* *$ & $* *$ & $* *$ \\
\hline
\end{tabular}

**indicate $\mathrm{P}<0.05, \mathrm{P}<0.01$ and not significant, respectively. Means of each factor designated by the same latter in a column are not significantly different at 0.05 level using Duncan's Multiple Range Test (DMRT).

Moreover, the single application of compost may suppress the microbial activities in the soil (Hargreaves et al., 2008).

Grain quality properties of Egyptian hybrid rice one cultivar as percentages of hulling, milling and head rice as affected by the application of compost and compost tea with chemical fertilizers (Table 6). Data clarified that the treatment $\mathrm{N}_{110} \mathrm{P}_{24} \mathrm{~K}_{40}$ (110 Urea: $24 \mathrm{P}_{2} \mathrm{O}_{5}: 40 \mathrm{~K}_{2} \mathrm{O} \mathrm{kg} \mathrm{ha-1}$ NPK) as two third of recommended doses of chemical NPK + basal application of compost as organic fertilizer + foliar spray of compost tea as bio-organic fertilizer in the permanent field at 40 days after transplanting (DAT) significantly enhanced grain quality characters. Then the treatment including foliar spray of compost tea with $\mathrm{N}_{110} \mathrm{P}_{24} \mathrm{~K}_{40}$ (110 Urea: $24 \mathrm{P}_{2} \mathrm{O}_{5}$ : $40 \mathrm{~K}_{2} \mathrm{O} \mathrm{kg}$ $\left.\mathrm{ha}^{-1} \mathrm{NPK}\right)$. Increasing all grain quality characters of Egyptian hybrid rice one cultivar may be due to the compost and compost tea contain significant amounts of valuable plant nutrients including $\mathrm{N}, \mathrm{P}, \mathrm{K}, \mathrm{Ca}, \mathrm{Mg}$ and $\mathrm{S}$ and a variety of essential trace elements (Smith and Collins, 2007; Quilty and Cattle, 2011; Fischer and Glaser 2012). Moreover, Compost can effectively be used to improve soil quality, soil hydraulic, and soil pore characteristics (Eusufzai and Fujii, 2012) in this case; compost and compost tea with chemical fertilizer can improve yield of Egyptian hybrid rice one cultivar and its grain quality characters. Untreated plots produced the lowest values similar trend was obtained by Wissa et al. (2016).

Grain and straw yield of Egyptian hybrid rice one cultivar as affected by the combinations of compost and compost tea with chemical fertilizers in 2015 and 2016 rice growing seasons, is presented in Table 7. The results indicated that grain and straw yield significantly increased with the application of $\mathrm{N}_{110} \mathrm{P}_{24} \mathrm{~K}_{40}$ (110 Urea: $24 \mathrm{P}_{2} \mathrm{O}_{5}$ : $40 \mathrm{~K}_{2} \mathrm{O} \mathrm{kg} \mathrm{ha}{ }^{-1} \mathrm{NPK}$ ) as two third of recommended doses of chemical NPK + basal application of compost as organic fertilizer + foliar spray of compost tea as bio-organic fertilizer in the permanent field at 40 days after transplanting (DAT) without any significantly differences with $\mathrm{N}_{165} \mathrm{P}_{36} \mathrm{~K}_{60}$ (165 Urea: $36 \mathrm{P}_{2} \mathrm{O}_{5}: 60 \mathrm{~K}_{2} \mathrm{O} \mathrm{kg} \mathrm{ha}{ }^{-1}$ ) as recommended NPK doses, similar trend was obtained by Elekhtyar (2016). Combinations of two third of recommended chemical NPK + compost as soil application + compost tea as foliar spray can save one third of recommended chemical NPK. Also able to improve Egyptian hybrid rice one cultivar and reducing inorganic fertilizers as well as minimizing the cost of inputs and environmental pollution (Elekhtyar et al., 2016).

Increasing yield of Egyptian hybrid rice one cultivar by combined the application of chemical and organic fertilizers may be due to an excessive supply of available nutrients that produced excessive vegetative growth, higher number of grains per panicle and higher percentage of filled grains. Moreover, combination of compost with chemical fertilizer containing $\mathrm{N}, \mathrm{P}$ and $\mathrm{K}$ has increased $\mathrm{P}$ uptake percentage by plants. They stated that increased activity of microorganisms of solution of inorganic $\mathrm{P}$ in the soil and high concentration of this element in compost and compost tea were the main reasons of increased absorption of $\mathrm{P}$ due to using compost (Soumare et al., 2003). Use of organic matter in the soil 
increased available $\mathrm{P}$ to plants and indirectly prevented phosphate deposits as iron phosphate, aluminum phosphate and calcium phosphate as non-absorbable for plants. In order to investigate the effect of compost on $\mathrm{K}$ uptake by rice plant it has been shown that due to the use of compost the amount of $\mathrm{K}$ uptake by grains and shoots of the plant was increased (Bhattacharyya et al., 2007).

Increased grain yield in relation to the use of compost can be due to improved soil organic matter, increased usability of N, P, K and reduced
$\mathrm{pH}$ in the soil (Aggelides and Londra, 2000). By increasing rates of compost and its tea, the concentration of macronutrients was increased in the soil and rice plant. Also the use of compost had a significant effect on the concentration of macronutrients in the rice plant grain and yield. (Ranjbar et al., 2016). Unfertilized treatment or fertilized with compost and compost tea without any chemical fertilizers recorded the lowest grain and straw yield in two seasons. Decreasing the yield with the single application of compost may

TABLE 6. Percentages of hulling, milling and head rice of Egyptian hybrid rice one cultivar $\left(\mathrm{H}_{1}\right)$ as affected by compost and compost tea in 2015 and 2016 seasons

\begin{tabular}{lcccccc}
\hline \multirow{2}{*}{ Treatments } & \multicolumn{2}{c}{ Hulling\% } & \multicolumn{2}{c}{ Milling\% } & \multicolumn{2}{c}{ Head rice\% } \\
& $\mathbf{2 0 1 5}$ & $\mathbf{2 0 1 6}$ & $\mathbf{2 0 1 5}$ & $\mathbf{2 0 1 6}$ & $\mathbf{2 0 1 5}$ & $\mathbf{2 0 1 6}$ \\
\hline $\mathrm{N}_{165} \mathrm{P}_{36} \mathrm{~K}_{60}$ & $78.02 \mathrm{bc}$ & $78.19 \mathrm{~b}$ & $67.88 \mathrm{c}$ & $67.48 \mathrm{c}$ & $62.74 \mathrm{~b}$ & $62.75 \mathrm{~b}$ \\
$\mathrm{~N}_{110} \mathrm{P}_{24} \mathrm{~K}_{40}$ & $77.05 \mathrm{c}$ & $76.79 \mathrm{~cd}$ & $65.62 \mathrm{e}$ & $66.04 \mathrm{~d}$ & $60.97 \mathrm{c}$ & $60.94 \mathrm{c}$ \\
$\mathrm{N}_{110} \mathrm{P}_{24} \mathrm{~K}_{40}+$ Compost & $77.03 \mathrm{c}$ & $77.04 \mathrm{c}$ & $66.97 \mathrm{~d}$ & $66.57 \mathrm{~cd}$ & $61.55 \mathrm{c}$ & $61.52 \mathrm{c}$ \\
$\mathrm{N}_{110} \mathrm{P}_{24} \mathrm{~K}_{40}+$ Compost tea & $78.60 \mathrm{~b}$ & $79.11 \mathrm{~b}$ & $69.04 \mathrm{~b}$ & $69.31 \mathrm{~b}$ & $63.00 \mathrm{~b}$ & $63.28 \mathrm{ab}$ \\
$\mathrm{N}_{110} \mathrm{P}_{24} \mathrm{~K}_{40}+$ Compost + Compost tea & $81.02 \mathrm{a}$ & $81.31 \mathrm{a}$ & $70.58 \mathrm{a}$ & $70.36 \mathrm{a}$ & $64.11 \mathrm{a}$ & $63.90 \mathrm{a}$ \\
Compost + Compost tea & $75.86 \mathrm{~d}$ & $75.81 \mathrm{de}$ & $64.69 \mathrm{f}$ & $64.74 \mathrm{e}$ & $59.78 \mathrm{~d}$ & $59.83 \mathrm{~d}$ \\
$\mathrm{~N}_{0} \mathrm{P}_{0} \mathrm{~K}_{0}$ & $75.21 \mathrm{~d}$ & $75.38 \mathrm{e}$ & $64.22 \mathrm{f}$ & $64.09 \mathrm{e}$ & $58.86 \mathrm{e}$ & $58.88 \mathrm{e}$ \\
F. test & $* *$ & $* *$ & $* *$ & $* *$ & $* *$ & $* *$
\end{tabular}

** indicate $\mathrm{P}<0.05, \mathrm{P}<0.01$ and not significant, respectively. Means of each factor designated by the same latter in a column are not significantly different at 0.05 level using Duncan's Multiple Range Test (DMRT).

TABLE 7. Grain yield and straw yield of Egyptian hybrid rice one cultivar $\left(\mathrm{H}_{1}\right)$ as affected by compost and compost tea in 2015 and 2016 seasons.

\begin{tabular}{|c|c|c|c|c|}
\hline \multirow[t]{2}{*}{ Treatments } & \multicolumn{2}{|c|}{ Grain yield $\left(\mathrm{t} \mathrm{ha}^{-1}\right)$} & \multicolumn{2}{|c|}{ Straw yield $\left(\mathrm{t} \mathrm{ha}^{-1}\right)$} \\
\hline & 2015 & 2016 & 2015 & 2016 \\
\hline $\mathrm{N}_{165} \mathrm{P}_{36} \mathrm{~K}_{60}$ & $10.35 \mathrm{ab}$ & $10.31 \mathrm{bc}$ & $14.42 \mathrm{ab}$ & $13.85 \mathrm{~b}$ \\
\hline $\mathrm{N}_{110} \mathrm{P}_{24} \mathrm{~K}_{40}$ & $9.18 \mathrm{~cd}$ & $9.60 \mathrm{c}$ & $13.03 \mathrm{~cd}$ & $11.74 \mathrm{~cd}$ \\
\hline $\mathrm{N}_{110} \mathrm{P}_{24} \mathrm{~K}_{40}+$ Compost & $9.97 \mathrm{bc}$ & $10.01 \mathrm{c}$ & $14.20 \mathrm{bc}$ & $12.59 \mathrm{c}$ \\
\hline $\mathrm{N}_{110} \mathrm{P}_{24} \mathrm{~K}_{40}+$ Compost tea & $10.83 \mathrm{a}$ & $10.87 \mathrm{ab}$ & $14.97 \mathrm{ab}$ & $14.42 \mathrm{ab}$ \\
\hline $\mathrm{N}_{110} \mathrm{P}_{24} \mathrm{~K}_{40}+$ Compost + Compost tea & $11.10 \mathrm{a}$ & $11.05 \mathrm{a}$ & $15.31 \mathrm{a}$ & $15.29 \mathrm{a}$ \\
\hline Compost + Compost tea & $9.03 \mathrm{~d}$ & $8.92 \mathrm{~d}$ & $12.84 \mathrm{~cd}$ & $11.45 \mathrm{~cd}$ \\
\hline $\mathrm{N}_{0} \mathrm{P}_{0} \mathrm{~K}_{0}$ & $8.89 \mathrm{~d}$ & $8.78 \mathrm{~d}$ & $11.63 \mathrm{~d}$ & $11.18 \mathrm{~d}$ \\
\hline F. test & $* *$ & $* *$ & $* *$ & $* *$ \\
\hline
\end{tabular}

* indicate $\mathrm{P}<0.05, \mathrm{P}<0.01$ and not significant, respectively. Means of each factor designated by the same latter in a column are not significantly different at 0.05 level using Duncan's Multiple Range Test (DMRT).

suppress the microbial activities of the soil since it has a high $\mathrm{C} / \mathrm{N}$ ratio. In this case, the soil microbe competes with crops to uptake the $\mathrm{N}$ (Amlinger et al., 2003), thus decrease yield of hybrid rice.

\section{Conclusion}

The results from this study support that the application of $\mathrm{N}_{110} \mathrm{P}_{24} \mathrm{~K}_{40}$ (110 Urea: $24 \mathrm{P}_{2} \mathrm{O}_{5}: 40$ $\mathrm{K}_{2} \mathrm{O} \mathrm{kg} \mathrm{ha-1} \mathrm{NPK}$ ) as two third of recommended doses of chemical NPK + basal application of compost as organic fertilizer + foliar spray of compost tea as bio-organic fertilizer in the permanent field at 40 days after transplanting (DAT) without any significantly differences with $\mathrm{N}_{165} \mathrm{P}_{36} \mathrm{~K}_{60}$ as recommended NPK doses were able to improve Egyptian hybrid rice one cultivar and reducing chemical NPK fertilizers by one third. 
In total, consumption of compost and compost tea increased nutrients concentration and yield of rice and minimized the use of chemical fertilizers and environmental pollution.

\section{References}

Adair, C. R. (1952) The McGill Miller method for determining the milled quality of small samples of rice. Rice J., 55(2): 21- 23 .

Aggelides, S. M. and Londra, P. A. (2000) Effects of compost produced from town wastes and sewage sludge on the physical properties of a loamy and a clay soil. Biore. Technol., 71(3): 253-259.

Amlinger, F., Gotz B., Dreher, P. and Weissteiner, C. (2003). Nitrogen in biowaste and compost: dynamics of mobilization and availability-a review. European J. Soil Bio., 39(3): 107-116.

Bhattacharyya, P., Chakrabarti, K., Chakraborty, A. and Nayak, D.C. (2005) Effect of municipal solid waste compost on phosphorous content of rice straw and grain under submerged condition. Arc. Agron. Soil Sci., 51(4): 363-370.

Bhattacharyya, P.,Chakrabarti, K., Chakraborty, A., Nayak, D.C., Tripathy, S. and Powell M.A. (2007) Municipal waste compost as an alternative to cattle manure for supplying potassium to lowland rice. Chemosphere, 66(9): 1789-1793.

Black, C. A., Evans, D. D., Ensminger, L. E., and Clark, F. E. (1965) Methods of Soil Analysis. Part 2- Chemical and microbiological properties. American Soc., of Agron. Inc., Publisher, Madison, Wisconsin, USA. (C. F. comp. Research).

Duncan, D. B. (1955) Multiple Range and Multiple F. Test. Biometrics. (11): 1-42.

Elekhtyar, N.M. (2007) Response of rice yield to application of nitrogen from different sources and forms. M.sc. Thesis, Fac. Agric., Kafrelsheikh Univ., Egypt.

Elekhtyar, N.M. (2011) Effect of bio and mineral nitrogen fertilizer on growth, yield and chemical composition of rice. Ph.D. Thesis, Fac. Agric., Kafrelsheikh Univ., Egypt.

Elekhtyar, N.M. (2015a) Efficiency of Pseudomonas fluorescens as Plant Growth-Promoting Rhizobacteria (PGPR) for the enhancement of seedling vigor, nitrogen uptake, yield and its attributes of rice (Oryza sativa L.). Int. J. Sci. Res. Agric. Sci. (IJSRAS), (2): 057 - 067.

Elekhtyar, N.M. (2015b) Impact of three strains of

J. Sus. Agric .Sci. 43, No. 3 (2017)
Bacillus as bio NPK fertilizers and three levels of mineral NPK fertilizers on growth, chemical compositions and yield of Sakha 106 rice cultivar. Int. J. ChemTech Res., 8 (4): 2150 - 2156.

Elekhtyar, N.M. (2016) Influence of different plant growth promoting rhizobacteria (PGPR) strains on rice promising line. Proc. of the sixth field crops Con., FCRI, ARC, Egypt. 6(P): $327-335$.

Elekhtyar, N.M., Metwally, T.F. and Nour El-Din, M. (2016) Evaluation of bio-NPK and compost tea on seedling vigor and yield of rice. Proceedings of $1 \mathrm{st}$ International Conference of Applied Microbiology -1(Proceedings): $8-20$.

Eusufzai, M.K. and Fujii, K.(2012) Effect of organic matter amendment on hydraulic and pore characteristics of a clay loam soil. Open J. Soil Sci. 2 (4), 372-381.

Fischer, D. and Glaser, B. (2012) Synergisms between compost and biochar for sustainable soil amelioration. Martin Luther University Halle Wittenberg, Institute of Agricultural and Nutritional Sciences, Soil Biogeochemistry, Halle, Germany, www.intechhopen.com, Management of Organic Waste, 167 - 198.

Gajalakshmi S. and Abbasi, S.A. (2008) Solid Waste Management by Composting: State of the Art', Critical reviews in environmental Sci. Technology, 38(5), 311-400.

Gomez, K.A. and. Gomez, A.A (1984) Statistical procedures for agricultural research. Jahn Wiley Sons, New York, USA.

Hafez, A.A.R. and Mikkelson, D.S. (1981) Colorimetric determination of nitrogen for evaluating the nutrition status of rice. Soil Sci. and Plant Analy., 12(1):61-69.

Hargreaves, J.C., Adl,M.S. and Warman, P.R. (2008) A review of the use of composted municipal solid waste in agriculture. Agriculture, Ecosystems and Environment, 123(1), 1-14.

Laboski, C.A. and Lamb, J.A. (2003) Changes in soil test phosphorus concentration after application of manure or fertilizer. Soil Sci. Soc. of America J., 67(2), 544-554.

Lal, R. (2009) Soils and food sufficiency: a review. Agronomy for Sustainable Development, 29, 113-133.

Nigussie, A., Kuyper T.W. and Neergaard, A. (2015) Agricultural waste utilisation strategies and demand for urban waste compost: evidence from smallholder farmers in Ethiopia. Waste Managt., 44, 82-93. 
Page, A.L., Miller, R.H. and Keeney D.R. (1982) Method of Soil Analysis-part 2. Amer. Sco. Agric. Inc. Madison.

Peterpurgski, A.V. (1968) Handbook of Agronomic Chemistry. Kolop publishing House, Moscow (In Russion PP. 29-86)

Quilty, J. and Cattle, S. (2011) Use and understanding of organic amendments in Australian agriculture: a review. Soil Research, 49, 1-26.

Ramadass, K. and Palaniyandi, S. (2007) Effect of enriched municipal solid waste compost application on soil available macronutrients in the rice field. Arc. of Agron. Soil Sci., 53(5): 497-506.

Ranjbar, M., Sadeghnejadtalouki, Gh., Ghajar Sepanlou, M., Sadegh-Zadeh, F. and Bahmanyar, M.A. (2016) Effects of long-term municipal waste compost application on the concentrations of macro elements and yield of rice. Int. J. Hum. Capital Urban Managt., 1(4): 243-252.

Smith, J.L. and Collins, H.P. (2007) Composting. In: Soil Microbiology, Ecology, and Biochemistry $\left(3^{\text {rd }}\right.$ edition), Paul, E.A., (Ed), pp. 483-486.

Soumare, M., Tack, F.M.G. and Verloo, M.G. (2003) Effects of a municipal solid waste compost and mineral fertilization on plant growth in two tropical agricultural soils of Mali. Biore. Technol., 86 (1), 15-20.

Surekha, K., Reddy, K.P.C., Kumari, A.P.P. and Sta Cruz, P. C. (2006) Effect of straw on yield components of rice (Oryza sativa L.) under rice-rice. cropping system J. Agron. Crop Sci. 192, 92-101.

Wang, M.C. and Yang, C.H. (2003) Type of fertilizer applied to a paddy-upland rotation affects selected soil quality attributes. Geoderma, (114), 93 - 108.

Wissa, M. T., Awad-Allah, M. M. A. and Elekhtyar, N. M. (2016) Response of Egyptian hybrid rice one cultivar to times of nitrogen application and foliar spraying of ascobien compound. J. Plant Production, Mansoura Univ. 7(6), 567 - 574.

Xie, W., Wang, G. and Zhang, Q. (2007) Potential production simulation and optimal nutrient management of two hybrid rice varieties in Jinhua, Zhejiang province, China. J. Zhejiang Univ. Sci. 8 (7),486-492. (C. F. Comp. Research).

(Received: 3/7/2017; accepted:18/9/2017)

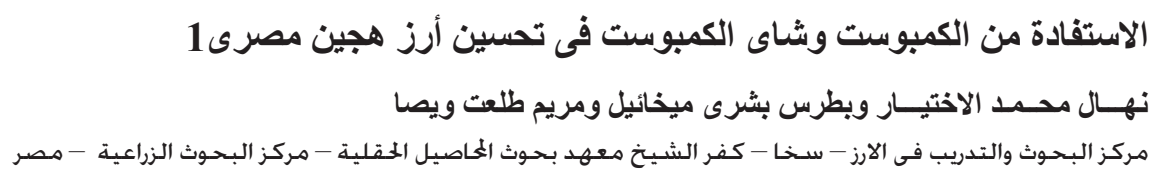

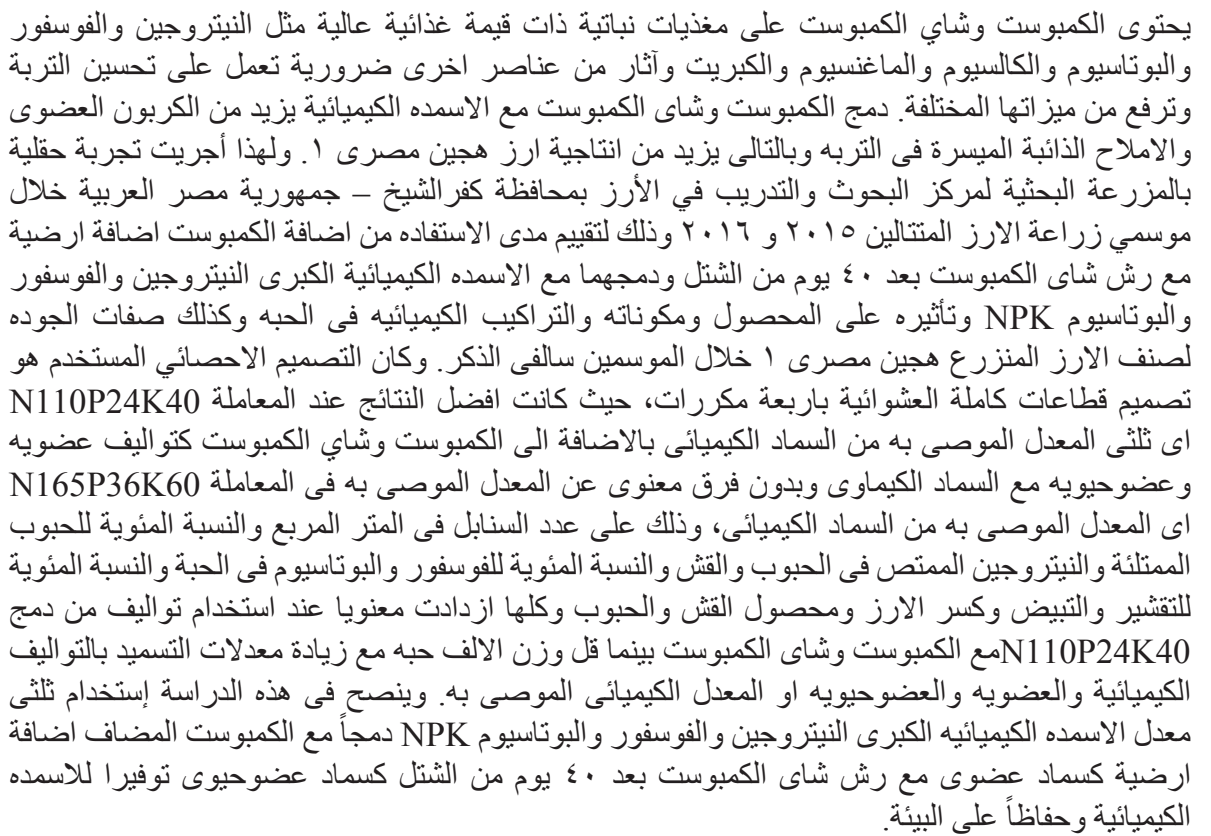

J. Sus. Agric .Sci. 43, No. 3 (2017) 